\title{
Diskursus Negara Pancasila di Kalangan Muhammadiyah
}

Said Romadlan ${ }^{1}$

saidromadlan@ui.ac.id ${ }^{1}$

${ }^{1}$ Mahasiswa Program Doktor Departemen Ilmu Komunikasi Universitas Indonesia, Jl. Margonda Raya, Kota Depok, 16424, Indonesia

\begin{abstract}
Abstrak
Artikel ini memfokuskan pada proses pemahaman atau penafsiran Muhammadiyah sebagai organisasi Islam berkemajuan atas Pancasila sebagai dasar negara. Pemahaman atas Pancasila sebagai dasar negara ini penting di tengah menguatkan arus ideologi transnasional yang hendak mendirikan negara Islam di Indonesia (khilafah) dan menggantikan dasar negara Pancasila dengan Islam. Selain itu, pengaruh globalisasi yang membawa nilai-nilai neoliberalisme pada berbagai praktik kehidupan berbangsa semakin memperlemah makna Pancasila. Di sisi yang lain, secara internal muncul juga pengkultusan dan klaim-kalim kebenaran atas makna Pancasila dari kelompok tertentu yang menyebut kelompok yang paling Pancasilais. Maka dari itu, tujuan artikel ini adalah hendak memahami bagaimana proses pemahaman yang dilakukan oleh Muhammadiyah sebagai organisasi Islam berkemajuan mengenai Pancasila sebagai dasar negara. Metode yang digunakan dalam studi ini adalah metode hermeneutika Paul Ricoeur yang menekankan penafsiran atas teks dengan proses penjarakan (distansiasi) antara teks dan pembaca. Hasil studi menunjukkan bahwa proses pemahaman terhadap Pancasila didasarkan bahasa (ayat) al-Qur'an surat Saba' ayat 15 "baldatun thayyibatun wa rabbun ghafur", yaitu suatu negeri yang baik dan berada dalam ampunan Allah. Dalam proses distansiasi bahasa menjadi diskursus, ayat tersebut ditafsirkan oleh Muhammadiyah sebagai Negara Pancasila. Selanjutnya, Negara Pancasila melalui distansiasi diskursus menjadi tekstualitas dipahami oleh Muhammadiyah sebagai darul abdi wa syahadah (negara hasil konsensus dan kesaksian). Pemahaman Muhammadiyah atas Negara Pancasila ini dapat dijadikan sebagai kontra-diskursus atas upaya-upaya kelompok islamis untuk mendirikan negara Islam di Indonesia.
\end{abstract}

Kata kunci: Diskursus, Hermeneutika, Muhammadiyah, Pancasila.

\begin{abstract}
This study focus on the process of understanding how Muhammadiyah is interpreted as Islamic organisation and Pancasila is as the ideology. The understanding toward Pancasila as the ideology is important because the Khalifah ideology appear to replace Pancasila. Furthermore, the drawback of globalisation which bring neoliberalism issue into society weaken the principles of Pancasila. In addition, destructive cult appears to claim that their movement/ organisation apply the most the principles of pancasila. This study aims to investigate the strategies used by Muhammadiyah in implementing the five principle of pancasila ad the ideology. This study used hermeneutika Paul Ricoeur methodology which emphasis on the interpretation on distantiation between text and reader. The findings mentioned that the understanding about Pancasila is rely in al-Qur'an's Saba verse 15 "baldatun thayyibatun wa rabbun ghafur", (a good country is in Allah's forgiveness). In discourse analysis, this verse is interpreted by Muhammadiyah that Indonesia is a country which is used pancasila as the ideology. They believe that Indonesia is darul abdi wa syahadab then this belief become cons discourse to against some movements to establish Khalifah Ideology.
\end{abstract}

Key Words: Discourse, Hermeneutic, Muhammadiyah, Pancasila. 


\section{Pendahuluan}

Setelah kekuasaan Orde Baru berakhir dengan lengsernya Soeharto pada tahun 1998, kelompok-kelompok Islam radikal transnasional yang selama itu menyembunyikan diri, menemukan momentumnya untuk bangkit dan menunjukkan eksistensinya. Salah satu kelompok Islam radikal yang bangkit itu adalah Hizbut Tahrir Indonesia (HTI) (Mubarak, 2007), selain kelompok-kelompok radikal transnasional lain seperti Ikhwanul Muslimin (IM) dari Mesir, Jamaah Tabaligh (JT) dari India, dan gerakan Negara Islam Indonesia (NII) yang berbentuk Jamaah Islamiyah (JI) (Hasan, 2008).

Hizbut Tahrir (HT) sendiri didirikan oleh Taqiy al-Din al-Nabhani di Pakistan tahun 1953. Di Indonesia HT diperkenalkan oleh Abd. Rahman al-Baghdadi di Bogor sekira tahun 1982-1983 (Hasan, 2008; Arif, 2018). HTI mendeklarasikan dirinya secara terbuka pasca-Soeharto turun dengan menggelar "Konferensi Khilafah Islamiyah" di Jakarta pertengahan tahun 2000. Pada akhir tahun 2000-an HTI bersama kelompok-kelompok Islam radikal lainnya menyelenggarakan Kongres Majelis Mujahidin I di Yogyakarta, yang memunculkan nama Abu Bakar Ba'asyir sebagai Amirul Mujahidin (Mubarak, 2007).

Gagasan utama HTI adalah mendirikan khilafah Islamiyah dan penerapan syariat Islam (Mubarak, 2007). Dengan tujuan mendirikan sistem khilafah sebagai bentuk negara maka sebenarnya HTI hendak mengganti Negara Kesatuan Republik Indonesia (NKRI) dengan Khilafah, dan mengganti Pancasila sebagai dasar dan ideologi negara dengan syariat Islam. Dalam pandangan HTI Pancasila adalah ideologi kufur, maka harus ditolak karena mengakomodir pluralisme agama (Arif, 2018). Meskipun begitu HTI tetap menerima Pancasila sebagai seperangkat falsafah. Sebagai falsafah Pancasila merupakan gagasan yang baik, meskipun dianggap tidak mencukupi untuk mengatur Indonesia. Karena selain hanya memiliki 5 sila, Pancasila tidak memiliki turunan sistematik dalam realitas politik dan kerangka ketatanegaraan. (Arif, 2018).

Pandangan HTI mengenai Pancasila sebagai ideologi kufur adalah salah satu bentuk penafsiran tentang Pancasila. Kontroversi pemahaman tentang Pancasila sudah terjadi sejak awal pendirian Republik Indonesia ini. Bahkan mengenai otentisitas Pancasila dan keabsahan kelahirannya pun diperdebatkan, apakah 1 Juni 1945 dalam pidato Soekarno, 22 Juni 1945 sebagaimana tercantum dalam Piagam Jakarta, atau 18 Agustus 1945 saat disahkan sebagai konstitusi negara? (Latif, 2015). Polemik mengenai makna Pancasila selama ini terutama berkaitan dengan penafsiran sila-silanya dan pemahamannya sebagai falsafah negara Indonesia atau sekadar persetujuan politik?

Studi yang dilakukan oleh Maarif mengenai Islam dan Pancasila sebagai Dasar Negara (2017) menunjukkan dinamika penafsiran tentang Pancasila pada masa awal-awal berdirinya Republik ini. Penafsiran terhadap Pancasila bisa bermacammacam, tergantung pada pandangan filosofis seseorang. Bagi M. Natsir (Masyumi), Pancasila itu bersifat sekuler karena sumber sila-silanya bukan wahyu Allah (Maarif, 2017). Roeslan Abdulgani (PNI) memandang sumber Pancasila adalah Islam, demokrasi liberal Barat, Marxisme, dan demokrasi asli Indonesia (Maarif, 2017).

Berkaitan dengan Pancasila sebagai dasar negara atau persetujuan politik, Sutan Takdir Alisyahbana (Sosialis) berpandangan bahwa Pancasila hanya kumpulan paham-paham yang berbeda untuk menentramkan semua golongan. Pancasila sebagai 
dasar negara adalah karena ia merupakan suatu kompromi politik (Maarif, 2017). Menurut Hatta berbeda, sila Ketuhanan Yang Maha Esa menjadi dasar yang memimpin sila-sila lainnya, dan merupakan prinsip pembimbing bagi cita-cita kenegaraan di Indonesia. Dengan menempatkan sila Ketuhanan Yang Maha Esa sebagai sila pertama, negara memperoleh landasan moral yang kukuh (Maarif, 2017).

Beberapa pemahaman mengenai Pancasila sejauh ini menunjukkan bahwa Pancasila adalah ideologi terbuka yang memungkinkan adanya bermacam-macam tafsiran filosofis. Beberapa kajian mengenai Pancasila menunjukkan beberapa sudut pandang pemahaman tentang Pancasila. Pertama, studi Eka Darmaputra (1997), yang mengkaji Pancasila melalui perspektif budaya Jawa. Kedua, studi Benjamin F Intan (2004), yang memahami Pancasila sebagai agama publik (public religion), yang menawarkan relasi antara agama dan negara yang melampaui batas-batas sekulerasasi dan islamisasi. Ketiga, studi Yudi Latif (2015), yang melakukan penafsiran-penafsiran kontekstual atas sila-sila Pancasila. Keempat, studi Syaiful Arif (2018), yang menggali pemikiran Gus Dur yang digunakan untuk pengujian Islam atas Pancasila.

Topik kajian ini memfokuskan pada proses pemahaman dengan pendekatan hermeneutika oleh Muhammadiyah atas Pancasila sebagai dasar negara. Kajian-kajian tentang Muhammadiyah lebih banyak berkaitan dengan isu politik dan gerakan pemikiran Muhammadiyah. Seperti studi Pradana Boy. ZTF. (2009), yang mengkaji mengenai pergulatan pemikiran dan praksis aliran pemikiran di tubuh Muhammadiyah. Syarifuddin Jurdi (2010), tentang sikap dan pandangan politik Muhammadiyah terhadap berbagai masalah, baik keislaman maupun Keindonesiaan. Studi Ridho Al-Hamdi (2013) tentang sikap elite Muhammadiyah terhadap 3 isu yaitu partai politik Islam, piagam Jakarta, dan terorisme. Terdapat 4 perilaku politik elit Muhammadiyah, yaitu transformatif-idealis, moderat-idealis, realistis-kritis, dan akomodatif-pragmatis.

Ruang lingkup studi ini dibatasi pada (1) Muhammadiyah sebagai gerakan Islam berkemajuan, (2) proses pemahaman dengan pendekatan hermeneutika Ricoeur, dan (3) Pancasila sebagai dasar negara. Sedangkan tujuan studi ini adalah (1) menunjukkan proses penafsiran yang dilakukan Muhammadiyah mengenai Pancasila sebagai dasar negara, (2) menjadikan hasil penafsiran sebagai kontra-diskursus atas upaya-upaya kelompok-kelompok Islam radikal yang hendak mengganti Pancasila sebagai dasar negara dan mengubah Indonesia menjadi khilafah islamiyah.

\section{Tinjauan Pustaka}

\section{Diskursus (Discourse)}

Diskursus adalah keseluruhan bidang (domain) di mana bahasa dipakai dalam cara-cara tertentu. Dalam diskursus pengetahuan itu dikonstruksi atau dibentuk, dan dihasilkan (Lubis, 2014). Diskursus (Fairclough, 1995), dapat dibagi dalam dua area, pertama dalam kajian bahasa diskursus adalah sebagai tindakan sosial dan interaksi, di mana orang-orang berinteraksi bersama dalam situasi sosial yang nyata. Kedua, diskursus dalam teori sosial post-strukturalis, yang memandang diskursus sebagai konstruksi realitas sosial, sebagai sebuah bentuk pengetahuan. Diskursus adalah bagian-bagian dari relasi komunikasi yang rumit antara orang-orang yang berbicara, menulis, dan cara-cara komunikasi seseorang dengan orang lain, juga menjelaskan hubungan antara peristiwa-peristiwa komunikatif (Fairclough, 2010). 
Kelle Lyytinen dan Rudy Hirschheim (1998) membedakan diskursus ke dalam empat bentuk, yaitu (1) explicative discourse, yakni berkaitan dengan ekspresi simbolik yang terbentuk dengan baik dan aturan yang sudah dianggap benar, (2) theoretical discourse, yaitu berkaitan dengan analisis mengenai teori atau klaim kebenaran yang masih kontroversial yang digunakan untuk mencapai tujuan, (3) therapeutic discourse, yaitu memberikan kritik terhadap invididu atau kelompok yang membohongi dirinya sendiri atau orang lain, dan (4) practical discourse, yaitu tindakan penyesuaian yang dilakukan berdasarkan norma-norma.

Paul Ricoeur mendefinisikan diskursus (discourse) yang terkait dengan hermeneutika, terutama pemahaman terhadap teks. Menurut Ricoeur teks adalah setiap diskursus yang dibakukan lewat tulisan. Maka, diskursus selalu terkait dengan penggunaan bahasa. Secara lebih khusus, Ricoeur (2006) merujuk bahasa sebagai peristiwa (event), yakni bahasa yang membicarakan tentang sesuatu. Jadi, diskursus adalah bahasa ketika ia digunakan untuk berkomunikasi (Permata, 2013). Diskursus menurut Ricoeur (2006) juga dapat disajikan sebagai sebuah peristiwa, yakni ada sesuatu yang terjadi ketika seseorang berbicara. Selain itu, diskursus juga merujuk pada dunia yang digambarkan, yang diungkapkan, dan diinterpretasikan.

Konsep diskursus digunakan karena fokus kajian ini adalah mengenai diskursus, yakni penggunaan bahasa untuk berkomunikasi. Diskursus yang hendak dikaji di sini berkaitan dengan penggunaan bahasa "Pancasila" sebagai dasar negara di kalangan Muhammadiyah. Melalui konsep diskursus ini dapat ditunjukkan pemahaman Muhammadiyah mengenai Pancasila. Diskursus Pancasila merujuk pada bahasa (ayat) al-Qur'an Surat Saba' ayat 15, "baldatun thayyibatun wa rabbun ghafur", yaitu suatu negeri yang baik dan berada dalam ampunan Allah. Bagi Muhammadiyah negeri yang dimaksud dalam ayat tersebut adalah Negara Pancasila, yang dalam diskursus dipahami sebagai darul abdi wa syahadah (Negara Konsensus dan Kesaksian).

\section{Hermeneutika}

Hermeneutika sebagai tradisi filsafat dikembangkan oleh Frederich Schleiermacher (1768-1834), untuk menafsirkan Bible, dan kemudian diterapkan pada penelitian ilmu manusia oleh Wilhelm Dilthey (1833-1911), serta beberapa filosof Jerman lainnya seperti Heidegger, Gadamer, dan Habermas, yang memfokuskan pada masalah penafsiran. Tentu Hermeneutika bukan soal menafsirkan semata. Gadamer misalnya mengatakan hermeneutika adalah memahami yang tujuannya adalah kesepahaman (Hardiman, 2015; Raharjo, 2014).

Hermeneutika berasal dari istilah Yunani hermeneuein dan hermenia yang berarti menafsirkan. Menurut Palmer (2005), kata hermeneuein dan bermenia memiliki arti (1) mengungkapkan kata-kata, (2) menjelaskan seperti menjelaskan situasi, dan (3) menerjemahkan seperti menerjemahkan ke dalam bahasa asing. Ketiga arti tersebut dapat diwakilkan dengan kata "to interpret". Josef Bleicher (1980) mendefinisikan hermeneutika sebagai teori atau filsafat mengenai penafsiran makna. Sedangkan Paul Ricoeur (2006) mendefinisikan hermeneutika berdasarkan cara kerjanya. Hermeneutika adalah teori tentang bekerjanya pemahaman dalam menafsirkan teks. Maka dari itu, hermeneutika tempatnya adalah bahasa, khususnya bahasa tulis.

Menurut Patton (2002), hermeneutika menyediakan kerangka teoritis untuk penafsiran, atau pemaknaan dengan secara khusus memperhatikan konteks dan tujuan awalnya. Istilah Hermeneutika, seringkali dihubungkan dengan kata Hermes, 
salah seorang dewa dalam mitologi Yunani Kuno. Hermes adalah dewa yang bertugas membawa pesan-pesan dewa kepada manusia. Agar pesan tersebut mudah dipahami manusia, Hermes menafsirkan dulu pesan dewa tersebut sebelum disampaikan kepada manusia (Lubis, 2014).

Dalam hermeneutika problem utamanya bukan pada pikiran pengirim (Tuhan) maupun pikiran penerima atau manusia. Tapi lebih pada peran Hermes dan kemampuannya dalam memahami wacana dari satu domain (Tuhan) dan menyampaikan pemahaman kepada domain manusia yang sangat berbeda. Hermeneutika dalam komunikasi meliputi dua-duanya, yakni antara teks yang masih asing yang kita berusaha memahaminya, dan dunia yang kita telah mengenalnya. Kita harus menjelaskan peleburan antara teks dengan konteks kontemporer yang telah kita baca (Radford, 2005)

Teori hermeneutika digunakan di sini karena kajian ini menggunakan perspektif hermeneutika untuk memahami diskursus tentang Pancasila di kalangan Muhammadiyah. Hermeneutika merupakan salah satu perspektif dalam memahami fenomena komunikasi melalui penafsiran atas bahasa yang digunakan dalam komunikasi. Dengan teori hermeneutika ini dapat diungkap penafsiran Muhammadiyah mengenai Pancasila sebagai dasar negara berdasarkan dokumendokumen resmi organisasi. Muhammadiyah menafsirkan Negara Pancasila sebagai darul abdi wa syahadah (Negara Konsensus dan Kesaksian).

\section{Teori Interpretasi}

Teori Interpretasi atau Teori Interpretif mengacu pada teori dan perspektif analisis dalam beberapa bidang seperti komunikasi, sosiologi, antropologi, pendidikan, kajian budaya, ilmu politik, sejarah, dan humaniora. Teori Interpretif dapat didefinisikan sebagai alat penelitian yang secara ontologi dan epistemologi memfokuskan pada pemahaman bagaimana individu-individu dan kelompokkelompok menciptakan makna dalam praktik kehidupan mereka sehari-hari, dalam komunikasi, dan dalam pengalaman hidup mereka (Littlejohn, 2009)

Teori Interpretasi Ricoeur fokus pada teks sebagai sebuah karya tulis yang memiliki otonomi tertentu. Teori interpretasi dapat dilihat sebagai satu jenis pembacaan yang merespon otonomi teks tersebut, dengan menggambarkan secara bersama-sama elemen pemahaman (verstehen) dan penjelasan (erklaren) dan menggabungkannya dalam satu proses interpretasi. Dalam hermeneutika, interpretasi adalah persoalan yang paling utama.

\section{a. Teks}

Dalam dunia teks, yang harus ditafsirkan adalah dunia yang dihamparkan oleh teks. Menurut Ricoeur (2006), dalam dunia teks, substansi teks atau dunia karya adalah media yang memperantarai kita untuk memahami diri kita sendiri. Dunia yang disuguhkan itu tidak terletak di belakang teks, sebagai maksud tersembunyi, melainkan berada di hadapan teks, sebagai sesuatu yang dibentangkan, ditemukan, dan diapungkan oleh sebuah karya. Oleh karena itu memahami adalah memahami diri sendiri di hadapan teks.

Maka dari itu Hardiman menyebut interpretasi Ricoeur sebagai refleksi (2014). Implikasinya adalah bahwa kegiatan interpretasi bukan sematamata menemukan makna dalam teks, seolah-olah makna adalah sebuah keniscayaan faktual. Memahami teks berarti mengaitkannya dengan makna 
hidup, yang itu dapat diperoleh melalui refleksi. Jadi, tidak ada interpretasi tanpa refleksi.

Lalu, apa yang disebut teks itu? Menurut Ricoeur (2006) teks itu adalah setiap diskursus yang dibakukan lewat tulisan. Dengan demikian, apa pun yang dibakukan melalui tulisan adalah diskursus yang memang dapat diucapkan. Jadi, pembakuan melalui tulisan menempati posisi ucapan. Lantas, bagaimanakah hubungan antara teks dan ucapan? Menurut Ricoeur, jika ucapan (parole) itu dipahami sebagai pengejawantahan bahasa (language) ke dalam sebuah peristiwa diskursus, maka setiap teks berada dalam posisi yang sama dengan ucapan dalam hubungan keduanya dengan bahasa.

\section{b. Penjelasan dan Pemahaman}

Paul Ricoeur menaruh perhatian paling serius mengenai perdebatan tentang penjelasan (erklaren) dan pemahaman (verstehen). Ricoeur mencari titik temu dengan meletakkan keduanya pada posisi berbeda tapi dengan fungsi yang saling melengkapi. Saat berhadapan dengan teks, terdapat dikotomi tatkala teks itu dicoba dimaknai, yaitu 'penjelasan' (explanation) dan 'penafsiran' (interpretation). Menurut Dilthey, 'penjelasan' merujuk pada penjelasan yang dipinjam dari ilmu alam. Sedangkan, 'penafsiran' merupakan bentuk derivasi dari pemahaman disiplin ilmu-ilmu kemanusiaan. Penafsiran ini dianggap sebagai satu-satunya perbedaan mendasar ilmu-ilmu kemanusiaan dengan ilmuilmu alam (Ricoeur, 2006).

Berkaitan dengan pandangan Ricoeur bahwa penjelasan dan pemahaman sebagai sebuah hubungan dialektis, Hardiman (2014) menyatakan bahwa setiap pemahaman tentang sebuah teks harus selalu dilengkapi dengan penjelasan sehingga dihasilkan pemahaman yang kritis. Ricoeur sepakat dengan Habermas untuk menggunakan kritik ideologi dalam hermeneutika, sebagai upaya interpretasi terhadap teks yang terdistorsi secara sistematis. Meskipun Habermas sendiri menganggap kritik ideologi tidak termasuk dalam hermeneutika, Ricoeur justru mengintegrasikan kritik ideologi dalam hermeneutika.

Pembedaan antara penjelasan dan pemahaman menurut Hardiman (2014) adalah berkaitan dengan pengambilan jarak atau penjarakan (distansiasi). Memahami adalah mengambil bagian, sedangkan menjelaskan adalah mengambil jarak. Memahami adalah menafsirkan, sedangkan menjelaskan adalah menganalisis. Dengan pendapat bahwa teks merupakan sesuatu yang otonom dari penulisnya, maka distansiasi melibatkan dua tahap dialektis. Pertama, perubahan bahasa menjadi diskursus dalam teks. Kedua, diskursus berkembang menjadi karya terstruktur. Proses menjadi teks ini disebut tekstualitas, dan dari itu dapat dilihat distansiasi teks dengan penulisnya atau teks dengan pembacanya.

\section{c. Hermeneutika sebagai Kritik Ideologi}

Salah satu perdebatan menarik dalam dunia hermeneutika adalah perdebatan antara hermeneutika filosofis Gadamer dan Teori Kritik Ideologi Habermas. Terdapat banyak hal yang diperdebatkan di situ, salah satunya adalah mengenai "tradisi'. Hermeneutika memandang tradisi sebagai sesuatu 
yang positif, sedangkan kritik ideologi memandang penuh kecurigaan bahwa tradisi sebagai komunikasi yang terdistorsi secara sistematis.

Paul Ricoeur tidak hendak berpihak pada salah satunya, tapi ingin memperlihatkan bahwa keduanya bisa saling mengakui klaim universalitasnya. Bisakah hermeneutika menjawab tuntutan kritik ideologi? Menurut Ricoeur, untuk menjadikan hermeneutika sebagai kritik ideologi diperlukan penegasanpenegasan. Pertama, fungsi 'penjarakan' dalam hermeneutika harus tetap dipertahankan. 'Penjarakan' ini berkaitan dengan 'otonomi teks'. Teks tidak lagi bersesuaian dengan maksud pengarang. Bentuk otonomi ini berdampak langsung pada terlepasnya 'substansi teks' dari cakrawala maksud pengarang. Dunia teks bisa melebar melebihi dunia pengarangnya.

Kedua, hermeneutika harus mampu mengatasi persoalan dikotomi antara 'penjelasan' (explanation) dan 'pemahaman' (understanding). Dikotomi ini muncul dari kenyakinan bahwa sikap 'penjelasan' pasti dipinjam dari metode ilmu-ilmu alam, dan tanpa pertimbangan yang absah metode 'penjelasan' ini digunakan dalam ilmu-ilmu kemanusiaan. Padahal, sebagaimana ditegaskan oleh Dilthey bahwa metode yang paling tepat dalam ilmu-ilmu kemanusiaan adalah 'pemahaman'. Maka dari itu Ricoeur (2006) menyodorkan model semiologi dalam ranah teks yang bisa meyakinkan bahwa tidak semua bentuk penjelasan bersifat naturalistik maupun kausalitas.

Ketiga, hermeneutika sebagai kritik ideologi melalui cara pendobrakan atas finalitas teks, atau 'substansi teks', yaitu semacam dunia yang dibukakan oleh teks. Maka, menurut Ricoeur (2006) dalam upaya menjawab kritik ideologi, hermeneutika tidak lagi mencari maksud yang tersembunyi di balik teks tetapi dunia yang dibentangkan di hadapan teks. Terakhir, hermeneutika menjadi kritik ideologi melalui subyektifitas dalam interpretasi. Di sini perhatian utama hermeneutika bukanlah menemukan maksud yang tersembunyi di balik teks, tapi membentangkan dunia yang ada di hadapannya. Maka pemahaman diri yang otentik adalah sesuatu yang bisa diarahkan oleh 'substansi teks'.

Kajian ini menggunakan Teori Interpretasi Ricoeur karena fokus kajian ini berkaitan dengan interpretasi atau penafsiran mengenai Pancasila sebagai dasar negara oleh Muhammadiyah. Penekanan Teori Interpretasi adalah pada otonomi teks, yakni penafsiran atas teks yang terbebas dari maksud pengarangnya. Dengan proses penjarakan atau distansiasi dalam proses penafsiran, Teori Interpretasi ini dapat membantu menemukan pemahaman-pemahaman yang lebih kontekstual atas teks. Seperti halnya dalam kajian ini, melalui proses distansiasi ditemukan pemahaman Muhammadiyah mengenai dasar negara Pancasila sebagai darul abdi wa syahadah (Negara Konsensus dan Kesaksian), dengan merujuk pada al-Qur'an Surat Saba' ayat 15, "baldatun thayyibatun wa rabbun ghafur", yaitu suatu negeri yang baik dan berada dalam ampunan Allah.

\section{Metode}

Studi ini menggunakan metode hermeneutika. Metode hermeneutika merupakan sebuah pendekatan yang secara mendasar memikirkan hubungan untuk memahami dan menafsirkan teks dan teks teologis. Gagasan utama dari hermeneutika adalah, dalam menganalisis sebuah teks makna dari sebuah teks itu harus dibawa 
keluar dari perspektif pengarangnya (Bryman, 2008). Dalam bidang komunikasi hermeneutika menjadi salah satu paradigma baru sebagai alternatif paradigma lama, yakni paradigma (rezim) transmisi yang telah lama dominan (Radford, 2005).

Subyek studi ini adalah Muhammadiyah sebagai organisasi Islam berkemajuan. Muhammadiyah adalah organisasi masyarakat yang didirikan oleh $\mathrm{KH}$. Ahmad Dahlan pada tahun 1912 di Yogyakarta. Ciri-ciri perjuangan Muhammadiyah adalah Muhammadiyah sebagai gerakan Islam, Muhammadiyah sebagai gerakan dakwah Islam amar ma'ruf nahi munkar, dan Muhammadiyah adalah gerakan tajdid (www.muhammadiyah.or.id).

Unit analisisnya adalah dokumen-dokumen, pernyataan resmi, hasil Muktamar, dan Tanwir Muhammadiyah, serta beberapa artikel di Majalah Suara Muhammadiyah, baik cetak maupun online. Jenis penelitiannya adalah deskripsi kualitatif, yang menekankan pada kualitas dan kedalaman data. Sedangkan teknik pengumpulan datanya menggunakan dokumentasi. Analisis datanya memakai analisis hermeneutika Ricoeur yang menekankan pada proses penjarakan dalam pemahaman terhadap suatu teks.

\section{Hasil dan Pembahasan}

\section{Hasil Kajian}

Berdasarkan keputusan Muktamar Muhammadiyah ke-47 di Makassar tahun 2015, Muhammadiyah memandang bahwa Negara Kesatuan Republik Indonesia (NKRI) adalah Negara Pancasila yang ditegakkan di atas falsafah kebangsaan yang luhur dan sejalan dengan ajaran Islam. Pemahaman Muhammadiyah mengenai bentuk negara Pancasila merupakan hasil pemahaman penafsiran atas ayat al-Qur'an surat Saba' ayat 15, "baldatun thayyibatun wa rabbun ghafur", yaitu suatu negeri yang baik dan berada dalam ampunan Allah.

Pemahaman Muhammadiyah mengenai bentuk negara Pancasila secara hermeneutika dapat dijelaskan melalui analisis hermeneutika sebagai berikut:

\section{a. Penjelasan (Explanation/Erkleren)}

Penjelasan (Explanation/Erkleren) adalah menganalisis teks dengan semantik-mendalam (indepth-semantic), yang meliputi:

1) Latar: bagian teks yang menjelaskan latar belakang teks untuk memahami arah atau tujuan pembuatan teks.

Muhammadiyah memahami Negara Pancasila sebagai bentuk negara yang sejalan dengan nilai-nilai ajaran Islam. Di sini ditegaskan mengenai latar pemahaman mengapa Muhammadiyah menerima Negara Pancasila adalah karena sesuai dengan nilai-nilai ajaran Islam. Pemahama ini ditegaskan sebagaimana dalam keputusan Muktamar Muhammadiyah ke-47 tahun 2015 di Makassar berikut:

"Pancasila sebagai dasar Negara Republik Indonesia adalab ideologi negara yang mengikat selurub rakyat dan komponen bangsa. Pancasila bukan agama, tetapi substansinya mengandung dan sejalan dengan nilai-nilai ajaran Islam, yang menjadi rujukan ideologis dalam kehidupan kebangsaan yang majemuk. Dengan demikian dapat dinyatakan babwa Pancasila itu Islami karena substansi pada setiap silanya selaras dengan nilai-nilai ajaran Islam."

2) Detil: bagian teks yang menjelaskan mengenai pentingnya teks dengan menampilkan teks yang menguntungkan pembuat teks secara lebih banyak. 
Muhammadiyah memahami bahwa Negara Pancasila merupakan hasil konsensus nasional (darul abdi) dan tempat pembuktian atau kesaksian (darrus syahadab). Pancasila merupakan kesepakatan bersama antara tokoh-tokoh pendiri bangsa yang mesti dijaga keberadaannya. Sekaligus Pancasila adalah arena kontestasi terbuka bagi siapa saja untuk memberikan makna Pancasila dan mengisinya dengan kepentingan bersama. Sebagaimana dijelaskan secara mendetil dalam dalam keputusan Muktamar Muhammadiyah ke-47 tahun 2015 di Makassar berikut:

"Babwa Negara Pancasila merupakan hasil konsensus nasional (darul abdi) dan tempat pembuktian atau kesaksian (darrus syahadah) untuk menjadi negeri yang aman dan damai (darus salam) menuju kehidupan yang maju, adil, makmur, bermartabat, dan berdaulat dalam naungan ridla Allah SWT. Pandangan kebangsaan tersebut sejalan dengan cita-cita Islam tentang negara idaman "baldatun thayyibatun wa rabbun ghafur", yaitu suatu negeri yang baik dan berada dalam ampunan Allab".

3) Maksud: bagian teks yang menjelaskan maksud pembuat teks dengan menguraikan teks secara lebih eksplisit.

Muhammadiyah berkomitmen menjadikan Negara Pancasila sebagai darus syahadah atau negara tempat bersaksi dan membuktikan diri. Di sini Muhammadiyah sebagai gerakan Islam berkemajuan berupaya memaknai Pancasila sesuatu dengan nilai-nilai keislaman dan mengisi Pancasila dengan nilai-nilai kemajuan. Sebagaimana dijelaskan secara mendetil dalam dalam keputusan Muktamar Muhammadiyah ke-47 tahun 2015 di Makassar berikut:

"Segenap umat Islam termasuk di dalamnya Mubammadiyah harus berkomitmen menjadikan Negara Pancasila sebagai darus syahadah atau negara tempat bersaksi dan membuktikan diri dalam mengisi dan membangun kebidupan kebangsaan yang bermakna menuju kemajuan di segala bidang kehidupan. Dalam negara Pancasila sebagai darus syahadah umat Islam harus siap bersaing (fastabiqul khairat) untuk mengisi dan memajukan kehidupan bangsa dengan segenap kreasi dan inovasi yang terbaik".

4) Praanggapan: bagian teks yang menjelaskan makna teks dengan menampilkan pernyataan yang sudah dianggap kebenarannya.

Muhammadiyah memiliki anggapan dirinya sebagai kekuatan strategis umat dan bangsa dengan pandangan Islam yang berkemajuannya, akan membangun Negara Pancasila. Pandangan Islam berkemajuan adalah Islam sebagai agama yang ajaran-ajaran selalu sesuai dengan konteks perkembangan jaman. Sebagaimana dijelaskan secara mendetil dalam dalam keputusan Muktamar Muhammadiyah ke-47 tahun 2015 di Makassar berikut:

"Muhammadiyah sebagai kekuatan strategis umat dan bangsa berkomitmen untuk membangun Negara Pancasila dengan pandangan Islam yang berkemajuan. Dalam pandangan Islam yang berkemajuan Muhammadiyah bertekad menjadikan Negara Indonesia sebagai Negara Pancasila yang berkemajuan".

\section{b. Pemahaman (Understanding/Verstehen)}

Pemahaman/Penafsiran (Understanding/Verstehen) adalah menafsirkan teks dengan interpretasi-mendalam (indepth interpretation), yang meliputi: 
1) Distansiasi/penjarakan: terlepasnya substansi teks dari maksud pengarangnya.

Muhammadiyah mendasarkan pemahamannya mengenai bentuk negara pada ayat al-Qur'an surat Saba' ayat 15 "baldatun thayyibatun wa rabbun ghafur", yaitu suatu negeri yang baik dan berada dalam ampunan Allah". Berkaitan dengan distansiasi atau penjarakan dalam pemahaman mengenai Muhammadiyah mengenai ayat di atas, maka terdapat dua proses distansiasi dalam pemahaman, yaitu:

Distansiasi 1: Bahasa menjadi diskursus, di mana bahasa, dalam hal ini ayat al-Qur'an surat Saba' ayat 15 baldatun thayyibatun wa rabbun ghafur atau negara yang baik dan dalam ampunan Allah SWT dipahami dalam diskursus oleh Muhammadiyah sebagai Negara Pancasila. Muhammadiyah menafsirkan Negara Pancasila-lah yang dimaksudkan dalam ayat tersebut, karena Pancasila sesuai dengan nilai-nilai ajaran Islam.

Distansiasi 2: Diskursus menjadi teks, di mana diskursus Negara Pancasila oleh Muhammadiyah dipahami sebagai hasil konsensus nasional (dar al abdi) dan tempat pembuktian (dar al syahadah). Pemahaman Muhammadiyah mengenai Negara Pancasila sebagai darul abdi wa syahadah kemudian oleh Muhammadiyah dibakukan dalam bentuk tekstualitas, yaitu proses perubahan dari diskursus menjadi teks dengan menjadikan pemahaman tersebut dalam keputusan resmi Muktamar ke-47 di Makassar tahun 2015.

Proses distansiasi pemahaman mengenai bentuk negara oleh Muhammadiyah dapat dilihat pada skema 1 berikut:

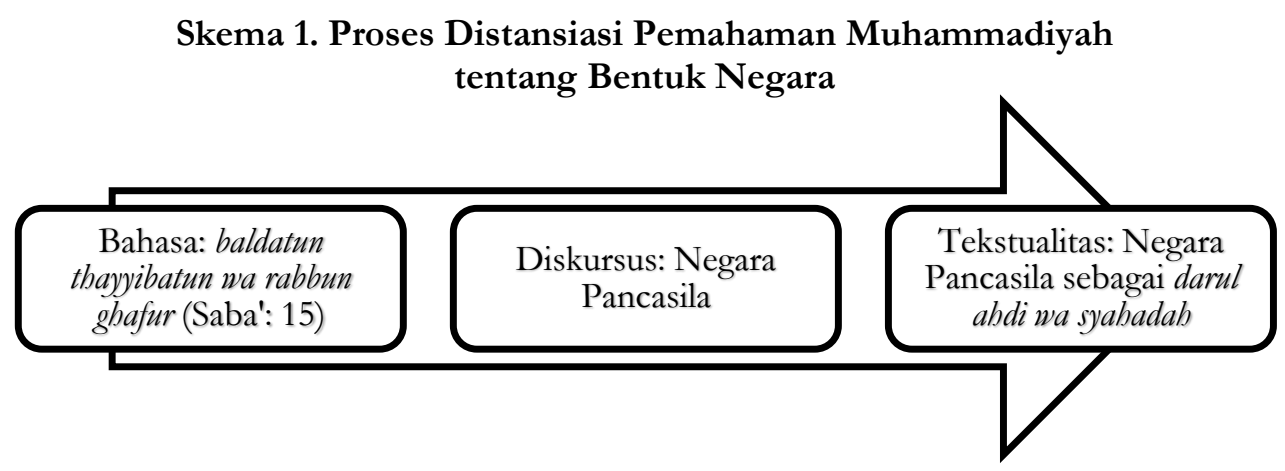

2) Rujukan/substansi teks: tidak lagi mencari maksud yang tersembunyi di balik teks tetapi memahami dunia yang dibentangkan di dalam teks.

Muhammadiyah sebagai organisasi Islam berkemajuan tidak lagi memahami baldatun thayyibatun wa rabbun ghafur sekadar sebagai suatu negeri yang baik dan berada dalam ampunan Allah, sebagaimana arti atau terjemahan bahasa dari ayat al-Qur'an tersebut. Atau dalam konteks pemaknaan di balik ayat al-Qur'an tersebut yakni merujuk pada sebuah negeri yang didoakan oleh Nabi Ibrahim, yaitu negara Saudi Arabia.

Muhammadiyah lebih memahami al-Qur'an surat Saba' ayat 15 tersebut dalam konteks yang sangat terbuka dan dihamparkan secara luas di depan teks atau ayat al-Qur'an tersebut. Di sini Muhammadiyah melakukan distansiasi atas ayat al-Qur'an surat Saba' ayat 15 sebagai Negara Pancasila, 
yang sama sekali tidak ada dalam ayat-ayat (nash) al-Qur'an. Dalam keputusan Muktamar Muhammadiyah ke-47 tahun 2015 di Makassar disebutkan bahwa:

"Babwa Negara Pancasila merupakan hasil konsensus nasional (darul abdi) dan tempat pembuktian atau kesaksian (darrus syabadah) untuk menjadi negeri yang aman dan damai (darus salam) menuju kehidupan yang maju, adil, makmur, bermartabat, dan berdaulat dalam naungan ridla Allah SWT. Pandangan kebangsaan tersebut sejalan dengan cita-cita Islam tentang negara idaman "baldatun thayyibatun wa rabbun ghafur", yaitu suatu negeri yang baik dan berada dalam ampunan Allab".

3) Subyektifitas (penafsiran): Memahami berarti membukakan diri melalui proses pendakuan dunia yang ditawarkan dan yang telah dibentangkan oleh interpretasi.

Pada tingkat ini Muhammadiyah sebagai gerakan Islam berkemajuan sudah menjadikan pemahaman mengenai bentuk negara yang paling ideal dan sesuai dengan nilai-nilai ajaran Islam adalah Negara Pancasila. Muhammadiyah menjdikan pemahamannya ini menjadi bagian yang diakui (pendakuan) dari Muhammadiyah berdasarkan penafsiran dan refleksi yang dilakukan Muhammadiyah terhadap ayat-ayat al-Qur'an, terutama surat Saba' ayat 15 sebagaimana disebutkan di atas. Dalam keputusan Muktamar Muhammadiyah ke-47 tahun 2015 di Makassar disebutkan bahwa:

"Mubammadiyah memandang bahwa Negara Kesatuan Republik Indonesia (NKRI) yang diproklamasikan 17 Agustus 1945 adalab negara Pancasila yang ditegakkan atas falsafah kebangsaan yang lubur dan sejalan dengan ajaran Islam".

"Negara Pancasila yang mengandung jiwwa, pikiran, dan cita-cita lubur sebagaimana termaktub dalam pembukaan UUD 1945 itu dapat diaktualisasikan sebagai "baldatun thayyibatun wa rabbun ghafur" yang berperikehidupan maju, adil, makmur, bermartabat, dan berdaulat dalam naungan ridla Allah SWT."

Secara ringkas analisis hermeneutika mengenai bentuk negara menurut Muhammadiyah dapat dilihat pada skema 2 model Hermeneutika Ricoeur di bawah berikut:

\section{Skema 2. Analisis Hermeneutika Ricoeur mengenai Bentuk Negara menurut Muhammadiyah}

\begin{tabular}{|c|c|}
\hline & $\begin{array}{l}\text { Otonomi Teks: } \\
\text { Distansiasi }\end{array}$ \\
\hline $\begin{array}{l}\text { PENJELASAN (Explanation/Erkleren): } \\
\text { a. Latar: Pancasila sejalan dengan } \\
\text { nilai-nilai ajaran Islam. } \\
\text { b. Detil: Pancasila merupakan hasil } \\
\text { konsensus. } \\
\text { c. Maksud: umat Islam harus } \\
\text { berkomitmen terhadap Pancasila. } \\
\text { d. Praanggapan: Muhammadiyah akan } \\
\text { membangun Pancasila dengan } \\
\text { pandangan Islam berkemajuan. }\end{array}$ & $\begin{array}{l}\text { PEMAHAMAN/PENAFSIRAN (Understanding/Verstehen): } \\
\text { a. Distansiasi/penjarakan: } \\
\text { - Bahasa: baldatun thayyibatun wa rabbun ghafur. } \\
\text { - Diskursus: Negara Pancasila } \\
\text { - Tekstualitas: Negara Pancasila sebagai darul abdi wa } \\
\text { syahadab. } \\
\text { b. Rujukan/substansi teks: memahami teks baldatun thayyibatun } \\
\text { wa rabbun ghafur sebagai negara Pancasila. } \\
\text { c. Subyektifitas (penafsiran): Negara Pancasila dapat } \\
\text { diaktualisasikan sebagai baldatun thayyibatun wa rabbun ghafur. }\end{array}$ \\
\hline
\end{tabular}




\section{Pembahasan}

Sebagai gerakan Islam berkemajuan Muhammadiyah memahami diskursus tentang Negara Pancasila sebagai Darul Abdi wa Syahadah (Negara konsensus dan pembuktian atau kesaksian). Menurut Abdul Mu'thi Sekretaris Umum Pimpinan Pusat (PP) Muhammadiyah, Pancasila itu Islami, maka warga Muhammadiyah harus menjaga keutuhan negara Pancasila itu, karena merupakan buah dari perjanjian para pendiri bangsa yang merupakan representasi masyarakat Indonesia. Warga Muhammadiyah harus mengisi, dan berpartisipasi bersama elemen bangsa lainnya untuk menjadikan Negara Pancasila itu sebagai negara ideal (Wawancara dengan Peneliti, 16 November 2018, di Gedung Dakwah PP Muhammadiyah, Menteng, Jakarta Pusat). Pemahaman Muhammadiyah tentang Negara Pancasila sebagai Darul Abdi wa Syahadah diputuskan pada Muktamar Muhammadiyah ke-47 tahun 2015 di Makassar, Sulawesi Selatan.

Bila dikaitkan dengan konsep diskursus, hermeneutika, dan teori Interpretasi Ricoeur, pemahaman Muhammadiyah Negara Pancasila sebagai Darul Abdi wa Syahadah maka dalam bagian ini setidak ada 2 topik penting untuk dibahas lebih mendalam. Pertama berkaitan dengan gagasan Ricoeur soal otonomi teks dan proses penjarakan (distansiasi) antara bahasa, diskursus, dan tekstualitas. Kedua, berkaitan dengan keinginan Ricoeur untuk menjadikan penafsiran (hermeneutika) sebagai kritik ideologi atas pemahaman teks yang maknanya terdistorsi secara sistematis dan hegemonik, salah satunya dengan penjarakan (otonomi teks) dan subyektifitas penafsiran pembaca teks.

Pertama, berkaitan dengan otonomi teks dalam bentuk penjarakan atau distansiasi, maka pemahaman Muhammadiyah mengenai Negara Pancasila sebagai Darul Abdi wa Syahadah secara hermeneutik merupakan puncak refleksi (pendakuan) atas pemahaman bahasa atau ayat al-Qur'an yang termaktub dalam surat Saba' ayat 15 , baldatun thayyibatun wa rabbun ghafur, sebuah negeri yang baik dan berada dalam ampunan Allah. Dalam proses pemahaman ini terdapat proses penjarakan dari bahasa menuju diskursus, yakni dari ayat al-Qur'an surat Saba' ayat 15, baldatun thayyibatun wa rabbun ghafur, sebuah negeri yang baik dan berada dalam ampunan Allah menjadi Negara Pancasila. Pada proses pemahaman Negara Pancasila menjadi Darul Abdi wa Syahadah, juga terjadi penjarakan dalam proses pemahaman dari diskursus menjadi teks (tekstualitas).

Dalam teori Interpretasi Ricoeur, pemahaman Muhammadiyah mengenai Negara Pancasila sebagai Darul Abdi wa Syahadah tentu tidak sekadar pemahaman yang didasarkan atas proses penjarakan dari diskursus menuju teks. Tetapi pemahaman itu sekaligus menjadi identitas diri, atau yang disebut Ricoeur sebagai pendakuan sebagai hasil refleksi atas pemahaman terhadap sebuah teks. Di sini Muhammadiyah sebagai gerakan Islam berkemajuan memosisikan dirinya sebagai organisasi yang mendukung Pancasila sebagai dasar negara, sekaligus menolak gagasan mengganti Pancasila dengan ideologi lain dan menolak gagasan sistem khilafah di Indonesia.

Pemahaman Muhammadiyah mengenai makna Negara Pancasila sebagai Darul Abdi wa Syahadah diperoleh dengan proses distansiasi, di mana makna teks tidak dicari di belakang teks tapi justru di depan teks, sehingga diperoleh makna yang lebih kontekstual. Termasuk penggunaan istilah Negara Pancasila, meskipun secara politik 
tidak ada, tapi oleh Muhammadiyah istilah Negara Pancasila ini digunakan untuk menegaskan bahwa Indonesia itu adalah Pancasila.

Demikian pula istilah Darul Abdi wa Syahadah yang memiliki dua dimensi waktu, yaitu masa lalu dan masa depan. Dimensi masa lalu berkaitan dengan proses penjadian Pancasila sebagai ideologi negara yang dihasilkan melalui konsensus antara segenap elemen pendiri bangsa. Dimensi ini oleh Muhammadiyah disebut darul abdi (Negara Konsensus). Sedangkan dimensi masa depan berhubungan dengan hendak dimaknai apa Pancasila itu saat ini dan pada masa mendatang. Dimensi masa depan ini oleh Muhammadiyah diistilahkan dengan darus syahadah (Negara Kesaksian). Bagi Muhammadiyah akan berjuang mengisi dan memaknai Pancasila dengan nilai-nilai ajaran Islam. Karena pada dasarnya Pancasila itu islami.

Kedua, berkaitan dengan keinginan menjadikan hermeneutika tidak sekadar sebagai alat memahami, tapi juga sebagai kritik ideologi. Maka di sini pemahaman Muhammadiyah tentang Negara Pancasila sebagai Darul Abdi wa Syahadah yang dihasilkan melalui proses hermeneutis, dapat juga dijadikan sebagai kritik ideologi. Kritik ini ditujukan kepada kelompok-kelompok Islam yang menolak Pancasila karena dianggap tidak Islam (kafir), dan sekaligus hendak mendirikan Negara Khilafah sebagai pengganti Negara Kesatuan Republik Indonesia (NKRI). Gagasan Negara Khilafah ini diusung oleh kelompok Islam Hizbut Tahrir Indonesia (HTI) yang bercita-cita menegakkan sistem pemerintahan khilafah di Indonesia (Arif, 2018).

Konsep khilafah sendiri berasal dari kata "khalifah" dalam ayat al-Qur'an surat al-Baqarah ayat 30 tentang penciptaan manusia sebagai wakil Tuhan di muka bumi. Tugas utama "khalifah" adalah memakmurkan kehidupan di muka bumi, bukan menegakkan "khilafah", yaitu kekhalifahan. Kekhalifahan ini merupakan sebuah lembaga politik pasca-Nabi Muhammad yang dikenal dengan istilah khulafaur rasyidin, yaitu Abu Bakar, Umar bin Khattab, Utsman bin Affan, dan Ali bin Abi Thalib. Khilafah dianggap berakhir dengan berakhirnya khulafaur rasyidin tersebut. Selanjutnya sistem politik yang dianut umat Islam adalah dinasti, yaitu Dinasti Umaiyyah, Dinasti Abbasiyah, dan Dinasti Utsmaniyah (Azra, 2016).

Maka dari itu, gagasan untuk mendirikan Negara Khilafah oleh HTI maupun Negara Islam oleh NII (Negara Islam Indonesia) di Indonesia, harus ditolak karena tidak sesuai dengan konteks jaman, mengandung kontradiksi, dan utopis (Azra, 2016). Di sini Muhammadiyah sebagai gerakan Islam berkemajuan tampil dengan menawarkan gagasan Negara Pancasila sebagai Darul Abdi wa Syahadah, sebagai kontra-diskursus atas gagasan Negara Khilafah dan Negara Islam. Kontradiskursus ini dapat dilakukan dengan terus memproduksi diskursus gagasan Negara Pancasila sebagai Darul Abdi wa Syahadah ini di berbagai platform media, baik media konvensional (Suara Muhammadiyah dan TVMu) maupun media digital seperti media-media sosial. Termasuk melalui pengajian sebagai bentuk komunikasi publik yang menjadi ciri gerakan Muhammasiyah juga penting untuk terus dilakukan oleh tokoh-tokoh Muhammadiyah.

\section{Kesimpulan}

Muhammadiyah sebagai organisasi Islam berkemajuan yang lahir bahkan sebelum kelahiran Negara Indonesia, memiliki tanggung jawab untuk terus menjaga Bangsa Indonesia untuk tetap tegak dan berdiri kokoh sebagai bangsa yang berdaulat. Maka dari itu, segala bentuk penyimpangan dan ancaman terhadap bangsa Indonesia 
harus dihadapi, termasuk adanya upaya untuk mengganti Pancasila maupun mengubah sistem pemerintahan dengan sistem lain, Islam sekalipun.

Bagi Muhammadiyah Negara Pancasila adalah yang paling ideal saat ini dan yang paling sesuai dengan nilai-nilai ajaran Islam. Maka dari itu Negara Pancasila harus dikuatkan, salah satunya seperti yang dilakukan Muhammadiyah, adalah memberi peneguhan atas makna Negara Pancasila itu sendiri. Muhammadiyah memahami melalui proses penafsiran (hermeneutika) bahwa Negara Pancasila sebagai Darul Abdi wa Syahadah (Negara Konsensus dan Negara Kesepakatan). Selain peneguhan, tentu pemahaman Muhammadiyah tersebut juga dapat digunakan sebagai kontra-diskursus atas gagasan atau ideologi dominan yang hendak menjadikan Indonesia sebagai Negara Khilafah dan mengganti ideologi Pancasila sebagai dasar negara.

Kajian ini merekomendasikan pentingnya perspektif penafsiran (hermeneutika) atas persoalan-persoalan yang muncul di tengah masyarakat. Dalam masalah radikalisme dan terorisme misalnya, selain perspektif sosiologis, psikologis, dan kultural untuk memahami persoalan tersebut, perspektif hermeneutika (komunikasi) juga penting sebagai sudut pandang untuk memahami persoalan. Bahwa persoalan radikalisme dan terorisme juga disebabkan karena pemahaman atas teks atau ayat-ayat al-Qur'an mengenai demokrasi, jihad, dan toleransi yang terlalu tekstual dan tidak sesuai dengan perkembangan jaman.

\section{Referensi}

Al-Hamdi, R. (2013). Islam and Politics: Political Attitudes of the Elites in Muhammadiyah 1998-2010. Indonesia Journal of Islam dan Muslim Societies, Vol. 3, No. 2, December 2013: 267-290.

Arif, S. (2018). Islam, Pancasila, dan Deradikalisasi Menegubkan Nilai Keindonesiaan. Jakarta: Elex Media Komputindo.

Azra, A. (2016). Transformasi Politik Islam Raikalisme, Khilafatisme, dan Demokrasi. Jakarta: Prenadamedia Grup.

Bleicher, J. (1980) Contemporary Hermeneutics: Hermeneutics as Method, Philosophy, and Critque. London: Routledge.

Boy, P. ZTF. (2009). Para Pembela Islam Pertarungan Konservatif dan Progresif di Tubuh Muhammadiyah. Depok: Gramata Publishing.

Bryman, A. (2008). Sosial Research Methods. Third Edition. New York: Oxford University Press.

Darmaputra, E. (1997). Pancasila, Identitas, dan Modernitas. Jakarta: PT BPK Gunung Mulia.

Fairclough, N. (1995). Media Discourse. New York: St. Martin's Press Inc.

Fairclough, N. (2010). Critical Discourse Analysis the Critical Study of Language. Edinburgh: Logman Applied Linguistics.

Hardiman, B.F. (2015). Seni Memahami Hermeneutika dari Schleiermacher sampai Derrida. Yogyakarta: Kanisius.

Hasan, N. (2008). Laskar Jihad Islam, Militansi, dan Pencarian Identitas di Indonesia PascaOrde Baru. Jakarta: LP3ES-KITLV.

Intan, B.F. (2004). Public Religion and The Pancasila-Base State of Indonesia. USA: Boston College. 
Jurdi, S. (2010). Muhammadiyah dalam Dinamika Politik Indonesia 1966-2006. Yogyakarta: Pustaka Pelajar.

Latif, Y. (2015). Negara Paripurna Historisitas, Rasionalitas, dan Aktualita Pancasila. Jakarta: PT Gramedia Pustaka Utama.

Littlejohn, S.W \& Foss, K. (2009). Encyclopedia of Communication Theory 1. London: Sage Publications.

Lubis, A.Y. (2014). Teori dan Metodologi Ilmu Pengetabuan Sosial Budaya Kontemporer. Jakarta: Rajawali Press.

Lyytinen, K. and Hirschheim, R. (1998). Information System as Rational Discourse: an Application of Habermas Theory of Communication Action. Scand. J. Mgmt. Vol. 4. 1/2. Pp 19-30.

Maarif, A.S. (2017). Islam dan Pancasila sebagai Dasar Negara Studi Perdebatan dalam Konstituante. Bandung: PT Mizan Utama.

Mubarak, M.Z. (2007). Genealogi Islam Radikal di Indonesia: Gerakan, Pemikiran dan Prospek Demokrasi. Jakarta: LP3ES.

Palmer, R. E. (2005) Hermenentika Teori Baru mengenai Interpretasi (Masnur Hery \& Damanhuri Muhammad). Yogyakarta: Pustaka Pelajar.

Patton, MQ. 2002. Qualitative Research \& Evaluation Methods. 3th Editon. London-New Delhi: Sage Publications.

Permata, A.N. (Mulyono, Eds). (2013). Belajar Hermeneutika Dari Konfigurasi Filosofis menuju Praksis Islamic Studies. Yogyakarta: IRCsoD.

Radford, G.P. (2005). On The Philosophy of Communication. Belmont: Wadswoth.

Raharjo, M. (2014). Dasar-dasar Hermenentika Antara Intensionalisme \& Gadamerian. Yogyakarta: Ar-Ruzz Media.

Ricoeur, P. (2006). Hermeneutika Imu Sosial (Muhammad Syukri). Yogyakarta: Kreasi Wacana.

\section{Wawancara}

Mu'thi, Abdul. (2018). Gedung Dakwah Pimpinan Pusat Muhammadiyah, Menteng, Jakarta Pusat, 16 November 2018. 